and his conclusions. This work aroused much interest but was given a mixed reception. Giuseppe Balsamo Crivelli, professor of natural history in the University of Milan, studied the causal fungus and named it Botrytis bassiana (now Beauveria bassiana), and confirmation of Bassi's findings was published in 1838 by the director of the Paris Natural History Museum, Victor Audouin, to whom Bassi had sent a copy of his monograph and an infected chrysalis. There were opponents, to whose opinions Bassi was perhaps unduly sensitive, but his results were well founded and convinced the unprejudiced.

The study of muscardine disease is Bassi's major achievement. In the years that followed, he issued a second edition of "Del Mal del Segno" (1837) and published additional observations on this disease. $\mathrm{He}$ also wrote lengthily on pellagra and cholera, on diseases of the mulberry, vine and potato, and on other topics. He received a number of honours from both Italian and foreign academies, and to commemorate the centenary of Pasteur's birth a collected edition ${ }^{4}$ of Bassi's writings was published in Italy in 1925 under the auspices of a national committee headed by Mussolini. The collected writings are supplemented by biographical data and by a bibliography which lists more than forty articles, all in Italian, bearing on Bassi's life and work. The most important account of Bassi in English is that by Major.

As with many other outstanding figures in the history of science, Bassi crystallized ideas which were becoming prevalent. The influence on Bassi of Spallanzani's views on spontaneous generation has already been implied, and Bassi must have been familiar with the frequent association of fungi with decay and disease. In England an illustrated observation on salmon disease of freshwater fish had been given as early as 1748, and in 1832 the zoologist, Richard Owen, when dissecting a flamingo which had died at the London Zoo, found the lungs lined with a vegetable mould and concluded that there were Entophyta as well as Entozoa. The trail became even warmer when, as cited by Bassi, Profs. Configliachi and Brugnatelli, of Pavia, suggested that the muscardine disease had a mycotic origin because of the fungus smell associated with silkworms killed by this disease; but to Bassi must go the credit of being more perceptive and persevering than his contemporaries. Bassi's work was in its turn the stimulus that led Schoenlein to discover the mycotic nature of favus in man and it certainly influenced both Gruby and Berkeley ; the latter including in his paper on potato blight the first illustration of Beauveria bassiana to be published in Britain.

Bassi, if given to verbosity, was a modest and at times almost diffident writer. He was generous to others but he appears not to have suffered fools gladly, for in the preface to "Del Mal del Segno", while appealing to savants and breeders for their observations, he warns them that "to save time and trouble I shall reply only to those which seem to me sufficiently founded in fact to be able to further in some way the progress of science and art". Bassi lived up to his motto: "Quando il Fatto parla Ragion tace, perchè la Ragione è figlia del Fatto, non il Fatto figlio della Ragione" ("When Fact speaks Reason is silent, because Reason is the child of Fact, not Fact the child of Reason").

I am much indebted to Prof. R. Ciferri, of the University of Pavia, for a microfilm of Bassi's monograph, for a portrait of Bassi, and for taking me on a pilgrimage to Lodi, and to Mr. P. J. Yarrow, of the University of Exeter, for translations from the Italian.

' Berkeley, M. J., J. Hort. Soc, 1, 9 (1846). (Reprinted in "Phytcpathological Classics", No. 12, 1948).

${ }^{2}$ Zakon, S. J., and Benedek, T., Bull. Hist. Med., 16, 165 (1944), give English translations of Gruby's papers.

3 Tortonese, E., Endeavour, 7, 92 (1948).

" "Opere di Agostino Bassi" (Pavia, 1925).

${ }^{5}$ Major, R. H., Bull. Hist. Med., 16, 97 (1944).

\title{
OBITUARIES
}

\section{Dr. Arthur Felix, F.R.S.}

THE sudden death of Dr. Arthur Felix on January 14 at the age of sixty-eight removes from the bacteriological world one who had made his home in Britain for nearly thirty years and who had come to occupy, in the niche he carved out for himself, a position of considerable authority. The work he had done, much of it as a young man, had earned for him an international reputation, and it was a source of great joy to himself and his friends when the value of his contributions was recognized in 1943 by his election to the Fellowship of the Royal Society. He was an excellent example of the group of investigators who, trained in the field of chemistry and physics, have turned their attention to bacteriology and added so much to our knowledge of medical scienoe.

Dr. Felix was born of Orthodox Jewish parents on April 3, 1887, in Silesia-now part of Poland-not far from Tarnow. $\mathrm{H}_{\theta}$ was educated at a German Gymnasium, and then went to Vienna, where he studied chemistry and took his doctorate. After a period of two years or so learning mycology under Lafar, he was called up on the outbreak of war in
1914, and attached to a laboratory in a field ambulance posted near Cracow. There he met Weil, associate professor of bacteriology at Prague, under whom his bacteriological training was begun. The two formed an admirable pair. Between them they observed a peculiar phonomenon that they rapidly adapted to the diagnosis of typhus fever, which was then prevalent on the Eastern front. The Weil-Felix reaction, as it was called, proved of immense value in the differential diagnosis of typhus from typhoid and other fevers of unknown origin, and stimulated a great deal of research to explain why it was possible to obtain a specific agglutination reaction with an organism playing apparently no part in the causation of the disease. Intimately bound up with this reaction was a curious variation observed by Weil and Felix in the behaviour of one of the strains-Proteus $X 1$ which was under some conditions motile and under others non-motile. The association of this change with the serological behaviour of the organism was quickly appreciated, and a distinction established between the loose floccular agglutination dependent on the flagella of the motile form and the compact granular agglutination dependent on the body or 
somatic substance present in both motile and nonmotile forms. These observations on Proteus were later found to fit in admirably with similar observations made several years previously by Smith and Reagh in the United States on a member of the Salmonella group, and provided the basis of a wide generalization on the antigenic structure of bacteria.

At the end of the First World War, Felix worked for a time at Prague and, after taking a three-months course in tropical medicine at Hamburg, moved in 1920 to Palestine, where he served as a hospital bacteriologist for some years. In spite of his attachment to Zionism, he was forced to the conclusion that Palestine could not offer him the opportunities for research that he wanted, and he gladly accepted an offer in 1927 by Prof. J. C. G. Ledingham to join the Lister Institute in London. There he settled down among congenial colleagues and added to his reputation by discovering the $V i$ antigen of the typhoid bacillus. In 1939 he was appointed to a post in the Emergency Public Health Laboratory Service, in which he built up what was later to become the Central Enteric Reference Laboratory and Buresu. His development of the $V i$-phage typing method for 'finger-printing' typhoid bacilli, which had been introduced by Craigie and Yen in 1938, attracted world-wide interest, and in 1947 Felix's laboratory at Colindale was designated the international reference laboratory for the phage-typing of these organisms. Felix retired from the Public Health Laboratory Service in 1954, and returned to the Lister Institute where, with a research grant, he was able to tidy up some of his unfinished work.

Dr. Felix married in 1923 Leah Gluckman, of Tel-Aviv, who survives him.

G. S. WIISON

\section{Prof. James Small}

Prof. James Small died on November 28 at the age of sixty-six. Born at Brechin, Forfarshire, he was educated at Brechin High School, the Pharma. ceutical Society's School, and Birkbeck College (University of London). After graduation he lectured for a brief period at Armstrong (now King's) College, University of Durham, and then at the outbreak of the First World War joined the Black Watch Regiment. $\mathrm{He}$ was wounded and invalided out of the Army in 1916, and returned after a period of convalescence to his appointment at Armstrong College. In 1916 he became lecturer in botany at Bedford College, University of London, and in the following year was appointed also lecturer at the Pharmaceutical Society. He left London in 1920 to take the chair of botany in The Queen's University, Belfast, succeeding Prof. R. H. Yapp. He was elected to the membership of the Royal Irish Academy in 1922, and to the fellowship of the Royal Society of Edinburgh in 1926. He held the chair at Belfast until his retirement in 1954, when the Senate of the University bestowed the title of emeritus professor upon him.

Small's first major research was on the Compositae. His work on this family was published as a New Phytologist monograph in 1919 under the title "The Origin and Devolopment of the Compositae", and for this research he received the degree of D.Sc. of the University of London. In 1922, Small contributed a chapter to J. C. Willis's book, "Age and Area", on the evolution of the Compositae, and this initiated a series of papers in which he joined Willis in rejecting natural selection as an explanation of the course of evolution, advocating instead the idea of a sudden origin of species. He drew evidence for this from several groups, plant and animal, but particularly from the diatoms and Foraminifera, which have fossil records suitable for quantitative analysis. Recondite in style, these studies on "quantitative evolution" have seemed to some almost perversely out of step with current evolutionary thought; yet by his intensive analysis, Small brought to light quite remarkable regularities in the evolutionary history of the groups that came under his attention, regularities which remain to be explained by any evolutionary theory claiming to have general validity.

His other main line of research concerned $p \mathrm{H}$ phenomena in plants. He devised a colorimetrical method for the determination of $p \mathrm{H}$ in plant tissues in the early nineteen-twenties, and the results of numerous observations were brought together in the Protoplasma monograph "Hydrogen-ion Concentration in Plant Cells and Tissues" in 1929. His book, " $p \mathrm{H}$ and Plants", was published in 1947, and another of a more general nature, entitled "Modern Aspects of $p \mathrm{H}^{\prime}$ ", in 1953. In this year also he wrote a contribution on "The $p \mathbf{H}$ of Plant Cells" to the current series of Protoplasmatologia monographs, and during his final illness he completed the correction of the proofs of a contribution on the estimation of $p H$ values in living tissues and saps to Paech and Tracey's "Modern Methods of Plant Analysis".

His work on $p \mathrm{H}$ led Small to an interest in stomatal mechanisms, on which he published several papers. He was also actively concerned with the problems of protoplasmic movement, and devised a technique for its study in living stems. His important observation of very high rates of cyclosis in living sieve-tube elements of marrow is often overlooked, despite its high significance in relation to solute translocation.

Small's many-sided work on evolution and plant physiology was recognized in 1951 by the award of the Makdougall-Brisbane Prize of the Royal Society of Edinburgh, for distinguished research published in the journals of the Society.

His early interest in pharmacognosy was responsible largely for the writing of Small's "Textbook of Botany" (first edition, 1921 ; fourth edition, 1937), which was intended principally for the use of medical and pharmaceutical students, and which in its encyclopsedic nature reflected its author's own vast acquaintance with morphological botany.

For practically a quarter of a century Small was a member of the committee of the British Pharmacopœia, and he served on the council of the Pharmaceutical Society of Northern Ireland from its inception. He wrote innumerable papers on the botanical characteristics of officinal plants, and contributed a long series of beautifully illustrated articles to the journal Food on the structure, properties and uses of drugs and spices.

From 1920, when winning a vest-pocket camera in a newspaper competition provided an introduction, Small had an enthusiastic interest in photography, both technical and artistic. He became keenly aware of the potentialities of photography for recording the structures of botanical objects in the magnification range $\times 1-20$, and his superb pictures taken with the Small-Watson camera have been widely published and exhibited. This activity gained him election to the fellowship of the Royal Photographic 